\title{
RED PALM OIL IN LAYING DUCKS DIETS: EFFECTS ON PRODUCTIVE PERFORMANCE, EGG QUALITY, CONCENTRATIONS OF YOLK CAROTENOIDS
}

\author{
YIFEI LU*; SHUNAN DONG**; HAITENG ZHOU*; LIGANG YANG*; ZHAODAN WANG*; \\ DA PAN*; XIAN YANG*; HUI XIA*; GUIJU SUN* and SHAOKANG WANG*
}

\begin{abstract}
Red palm oil (RPO) has high nutritional value but it has not been widely used as poultry feed material. The aim of this study was to examine the short-term effects of RPO as poultry feed material on laying performance, egg quality, egg yolk colour, content of carotenoids and fatty acid profile in the yolk. Eightyfour Khaki Campbell ducks (50 weeks of age) were studied for eight weeks to examine the effects of RPO on the above characteristics. Dietary treatments were as follows: i) Control group (contains $30 \mathrm{~g} \mathrm{~kg}^{-1}$ soyabean oil), ii) $10 \mathrm{~g} \mathrm{~kg}^{-1} \mathrm{RPO}\left(10 \mathrm{~g} \mathrm{~kg}^{-1} \mathrm{RPO}+20 \mathrm{~g} \mathrm{~kg}^{-1}\right.$ soyabean oil), iii) $20 \mathrm{~g} \mathrm{~kg}^{-1} \mathrm{RPO}\left(20 \mathrm{~g} \mathrm{~kg}^{-1} \mathrm{RPO}+10 \mathrm{~g}\right.$ $\mathrm{kg}^{-1}$ soyabean oil), and iv) $30 \mathrm{~g} \mathrm{~kg}^{-1} \mathrm{RPO}$ (contains $30 \mathrm{~g} \mathrm{~kg}^{-1} \mathrm{RPO}$ ). RPO supplementation increased feed intake, improved the yolk egg colour, and increased the content of lutein, $\beta$-carotene and total carotenoids in egg yolk $(P<0.05)$. Dietary RPO could reduce serum triglyceride levels in laying ducks as well as total cholesterol (TC) and triglyceride (TG) levels in egg yolk. Our further studies also found that the saturated fatty acid (SFA) and monounsaturated fatty acid (MUFA) contents of duck egg yolks in experiment group were significantly higher than those in the control group $(P<0.001)$. Therefore, feeding of RPO can produce natural, healthy red-yolk eggs. The suitable RPO concentration is $20 \mathrm{~g} \mathrm{~kg}^{-1}$.
\end{abstract}

\section{Keywords: red palm oil, laying ducks, egg quality, yolk carotenoids, egg colour.}

Received: 9 July 2020; Accepted: 24 November 2020; Published online: 23 February 2021.

\section{INTRODUCTION}

Eggs are accepted to be consumed by most people worldwide, either as such or as food ingredients (Fraeye et al., 2012). Egg yolk colour is regarded as a major concern to consumers as it affects their purchasing behaviour (Fletcher, 1999), and the colour of yolk mainly depends on the content of

\footnotetext{
Key Laboratory of Environmental Medicine Engineering of Ministry of Education, Department of Nutrition and Food Hygiene, School of Public Health, Southeast University, Nanjing Jiangsu 210009, People's Republic of China.

** Kunshan Center for Disease Control and Prevention, Kunshan 215301, Jiangsu, People's Republic of China. E-mail: gjsun@seu.edu.cn
}

carotenoids and vitamin $B_{2}$ in egg yolk (Spasevski et al., 2020).

However, laying birds are mostly incapable of synthesising carotenoids and carotenes have low deposition efficiency in egg yolks and thus, must obtain them through their diet (Hammershoj et al., 2010). The intensity of yolk colour from normal feeding, such as corn-soya diet, is usually ranked seven from Roche's colour fan scale, whereas a scale of more than 10 is more preferable (Kijparkorn et al., 2010). Currently, a majority of commercial eggs are produced by supplementing the fodder of ducks with commercial feed colourants, which is mainly canthaxanthin. It produces a deeper egg yolk colour than can be achieved by feeding with wheat, soya, barley or corn. However, consumers are always worried about the safety of the commercial 
feed colourants. According to European Food Safety Authority, because of the absence of data, canthaxanthin has been considered as an irritant to the skin and eyes, as a skin sensitiser and is hazardous when inhaled (Additives and Products or Substances used in Animal, 2014). Besides, these products are banned in organic production, which rely mainly on yellow plant sources (Abiodun et al., 2014).

Crude palm oil (CPO) comes from oil palms. After using a modified physical refining process (Keat et al., 1991; Ooi et al., 1993; Go et al., 2015), a refined palm oil is produced. This refined palm oil retains most of the carotenoids and the vitamin E originally present in $\mathrm{CPO}$, and is named red palm oil (RPO) (Keat et al., 1991; Rauchova et al., 2018). RPO gets its colour because it contains high concentrations of carotenoids, especially betacarotene and alpha-carotene (Sundram et al., 2003). RPO contains approximately $500 \mathrm{ppm}$ carotene, 90\% presence of $\alpha$ - and $\beta$-carotene. The vitamin $\mathrm{E}$ content is about $800 \mathrm{ppm}, 70 \%$ of which is in the form of tocotrienols (mainly as $\alpha-, \beta-$, and $\delta$-tocotrienols) (Andreu-Sevilla et al., 2009; Rice and Burns, 2010). Other valuable minor components present in this oil are ubiquinones and phytosterols (Nagendran et al., 2000).

$\mathrm{RPO}$ has 50\% saturated fatty acid (SFA) (palmitic acid, C16:0), 40\% monounsaturated fatty acid (MUFA) (oleic acid, C18:1) and 10\% polyunsaturated fatty acid (PUFA) (linoleic acid, C18:2) (Ma, 2015). Excessive saturated fats increase the risk of cardiovascular diseases (CVD), while unsaturated fats are considered less harmful. Since $\mathrm{RPO} /$ palm oil (PO) has similar fatty acid profile and content, which contains approximately $50 \%$ of SFA, it has been reported that dietary PO induces platelet aggregation, which leads to an increase in venous thrombosis and increases serum triglyceride levels in rats (Mizurini et al., 2011).

As hyperlipidemia is usually caused by a highfat diet, palm oil, being partially saturated, has been suspected to be the cause of hyperlipidemia and CVD. However, studies have also shown that dietary RPO/PO does not increase subcutaneous fat and total fat in mice (Gouk et al., 2013), therefore does not cause hyperlipidemia and increase the risk of CVD (Go et al., 2015). Instead, it has a tendency to lower cholesterol and even has antithrombotic effects (Hornstra, 1987). Wilson et al. found that in comparison to other dietary oils rich in SFA 16:0, RPO/PO has been shown to reduce plasma cholesterol levels (Wilson et al., 2005), explained by the sn-2 theory. The positions of fatty acid attachment on the glycerol backbone are referred to by stereospecific numbers, (sn) $-1,-2$ and -3 . The attachment of a particular fatty acid to a particular position has an important effect on the fat/oil properties.
In $\mathrm{PO}$, oleic acid is predominantly situated at the sn-2 position, while long-chain SFA is predominantly situated at the sn-1,3 position. The subcutaneous, visceral as well as total fat deposition in mice all had correlated negatively with the total SFA content at the sn- 1,3 positions, while no relationships were found for MUFA and PUFA. The present results show that the positional distribution of long-chain SFA exerts a more profound effect on body fat accretion than the total SFA content (Wilson et al., 2005). RPO has been known as an excellent source of pro-vitamin A carotenoids for decades. However, the usage of RPO as poultry feed to increase egg yolk colour remains rarely researched. Most studies have focused on the effect of $\mathrm{PO} / \mathrm{RPO}$ on lipid metabolism in poultry and on the oxidative stability of poultry eggs (Nawab et al., 2019; Nyquist et al., 2013).

Nyquist et al. (2013) replaced animal fat with PO and RPO had no negative effects on chicken muscle nutritional value with regard to fatty acid composition and RPO decreased plasma total cholesterol (TC), confirming the TC reducing effect of this dietary oil. A study showed that RPO could be used effectively to reduce egg lipid and cholesterol content and also to increase the linoleic acid content without altering their acceptability of the eggs from hens (Chaturvedi and Chaturvedi, 2000). Another experiment showed that yolk colour and oxidative stability of chicken eggs from Institute of Selection Animals (ISA) brown hens had markedly improved $(P<0.05)$ with corresponding increase of CPO in the diets (Akter et al., 2014). Cherian et al. drew similar conclusion that $\mathrm{PO}$ (oils at $3.5 \%$ ) resulted in a significant $(P<0.05)$ reduction in 2-thiobarbituric acid values in eggs compared with menhaden oil and flax oil $(P<0.05)$, and it may suggest that dietary PO reduced lipid oxidation in egg yolk, which may be related to the rich carotenoid and/or vitamin $\mathrm{E}$ in CPO/PO (Cherian et al., 1996).

$\mathrm{RPO}$ is a commercially available feedstuff, highly rich in carotenoids and vitamin E. Carotenoids and vitamin $\mathrm{E}$ have strong antioxidant properties and effects. Previous studies have suggested that natural red-yolk egg could be produced naturally by feeding poultry with carotenoid-rich fodder such as Lucerne (Karadas et al., 2006), sano flower (Kijparkorn et al., 2010). Supplying egg-laying ducks with RPO may affect the colour of its egg yolk. However, research on the usage of RPO as poultry feed to increase egg yolk colour is still lacking. Therefore, the objectives of this study were to determine the effectiveness of layer diet supplementation with RPO on: 1) productive performance and egg traits during eight-week period from ducks aged 50-58 weeks, 2) the change of the yolk colour after eight-week intervention, and 3) the change of egg yolk carotenoids concentrations after eight-week intervention. 


\section{MATERIALS AND METHODS}

\section{Chemicals}

Petroleum ether, acetone and dichloromethane were of analytical grade, provided by Sinopharm; Methanol, acetonitrile (Merck, USA) and methyl tert-butyl ether (Sigma, USA) was chromatographic pure; $\beta$-carotene, lutein and zeaxanthin were obtained from Sigma. RPO used for the study was supplied by Malaysian Palm Oil Board (MPOB).

\section{Animal Management and Treatments}

The methods were carried out in accordance with the relevant guidelines and regulations concerning the use of animals in research. This study was conducted in accordance with the Declaration of Helsinki, and the protocol was approved by the Animal Experimental Ethical Inspection Form of Southeast University (20160501007) on 1 May 2016 (Nanjing, China).

A total of 84 Khaki Campbell ducks, aged 50 weeks and with similar body weights $(2.41 \pm 0.35 \mathrm{~kg})$ were used for this study. Ducks were put at random into four treatment groups (three replicates and seven ducks per replicate). The experimental ducks were fed different diets for eight weeks. The ducks were fed four experimental diets: i) contains $30 \mathrm{~g}$ $\mathrm{kg}^{-1}$ soyabean oil (control group), ii) $10 \mathrm{~g} \mathrm{~kg}^{-1} \mathrm{RPO}+$ $20 \mathrm{~g} \mathrm{~kg}^{-1}$ soyabean oil (10 $\mathrm{g} \mathrm{kg}^{-1} \mathrm{RPO}$ group), iii) $20 \mathrm{~g}$ $\mathrm{kg}^{-1} \mathrm{RPO}+10 \mathrm{~g} \mathrm{~kg}^{-1}$ soyabean oil $\left(20 \mathrm{~g} \mathrm{~kg}^{-1} \mathrm{RPO}\right.$ group), and iv) contains $30 \mathrm{~g} \mathrm{~kg}^{-1} \mathrm{RPO}\left(30 \mathrm{~g} \mathrm{~kg}^{-1} \mathrm{RPO}\right.$ group). The diets (Table 1) were isocaloric and isonitrogenous containing $177.3 \mathrm{~g} \mathrm{~kg}^{-1}$ crude protein (CP) and 12.2 MJ of metabolisable energy (ME) $\mathrm{kg}^{-1}$ of diet. The diets were supplemented with a commercial feed premix (Huamu Technology Company Ltd., Wuhan, China). All diets were formed into pellets to reduce differences in feed physical form, to ensure the same quality and to prevent feed selection by ducks (Buchanan and Moritz, 2009). Water was provided ad libitum until the end. Food was offered twice daily, approximately at $7.00 \mathrm{am}$ and $15.00 \mathrm{pm}$. The excrements were cleared every evening, with light hours maintained at $16 \mathrm{hr}$ day $^{-1}$. It was ensured that natural ventilation and hygiene was maintained throughout the study. Vaccines and medication are provided under the supervision of a veterinarian.

\section{Performance and Egg Quality Parameters}

All eggs were collected and egg production was calculated daily until the end of the experimental period. The weight, Haugh Unit and the yolk colour of each egg (10 per group) was measured weekly by EMT-5200 multi-function egg analyser (Robotmation, Japan). The albumen and egg
TABLE 1. INGREDIENT AND CHEMICAL COMPOSITION OF THE CONTROL GROUP'S DIET $\left(\mathrm{g} \mathrm{kg}^{-1}\right)$

\begin{tabular}{lc}
\hline Ingredient & $\mathrm{g} \mathrm{kg}^{-1}$ \\
\hline Corn & 610 \\
Soyabean meal & 240 \\
Wheat bran & 40 \\
Limestone power & 50 \\
Soyabean oil & 30 \\
Fish meal & 20 \\
$5 \%$ premix* & 10 \\
Nutrient & \\
Crude protein & 177.3 \\
Lys & 9.1 \\
Met & 3 \\
Crude fat & 58.9 \\
Calcium & 20.2 \\
Total P & 4.1 \\
Metabolisable Energy, $\mathrm{MJ} \mathrm{kg}^{-1}$ of diet & 12.2 \\
\hline
\end{tabular}

Note: * The premix provided the following per $\mathrm{kg}$ of diets, retinol $\geq 60 \mathrm{KIU} \mathrm{kg}$, cholecalciferol $\geq 48 \mathrm{KIU} \mathrm{kg}{ }^{-1}$, tocopherol $\geq 320 \mathrm{IU}$, menadione $\geq 40 \mathrm{mg} \mathrm{kg}^{-1}$, thiamin $\geq 11 \mathrm{KIU} \mathrm{kg}{ }^{-1}$, riboflavin $\geq 52 \mathrm{KIU} \mathrm{mg} \mathrm{kg}^{-1}$, vitamin $\mathrm{B}_{6} \geq 65 \mathrm{mg} \mathrm{kg}^{-1}$, cobalamin $\geq 0.3 \mathrm{mg} \mathrm{kg}^{-1}$, niacin $\geq 560 \mathrm{mg} \mathrm{kg}^{-1}$, pantothenic acid $\geq 160 \mathrm{mg} \mathrm{kg}^{-1}$, folic acid $\geq 16 \mathrm{mg} \mathrm{kg}^{-1}$, biotin $\geq 1.4 \mathrm{mg} \mathrm{kg}^{-1}$, choline chloride $\geq 9000 \mathrm{mg} \mathrm{kg}^{-1}, 20-500 \mathrm{mg} \mathrm{kg}^{-1}$ of Cu, 700-10 $000 \mathrm{mg} \mathrm{kg}^{-1}$ of Fe, $800-2800 \mathrm{mg} \mathrm{kg}^{-1}$ of Zn, 900-2900 mg kg-1 of $\mathrm{Mn}, 27 \mathrm{mg} \mathrm{kg}^{-1}$ of I, 2-9.6 $\mathrm{mg} \mathrm{kg}^{-1}$ of Se.

** Values were calculated from data provided by Feed Database in China (2013).

yolk were then separated and each egg yolk was stored at $-20^{\circ} \mathrm{C}$ before further analysis. Each yolk was extracted and analysed in triplicates for each method. Feed consumption was registered weekly per group and feed conversion ratio was calculated as grams of feed per grams of egg. Duck mortality was recorded as it occurred. Data recording began seven days prior to the experimental period.

\section{Extraction and Analysis of Diet and Yolk Total Carotenoids and Individual Carotenoids}

Carotenoids from the extracted egg yolk and carotenoids standards were analysed by using a high performance liquid chromatography (HPLC) system. Commercial standards of relevant carotenoids were used for quantification by dissolving them in dichloromethane to the following concentrations $\left(\mu \mathrm{g}\right.$ litre $\left.{ }^{-1}\right)$ : $\beta$-carotene $2.16,3.24,5.4,10.8,21.6,32.4$, 54 and $108 \mathrm{mg}$ litre $^{-1}$, lutein 1, 3, 4, 6, 10, 20 and 30 mg litre ${ }^{-1}$ and zeaxanthin 1, 2, 3, 4, 5, 10, 15, 20 and 50 $\mu \mathrm{g} \mathrm{ml}^{-1}$. The solutions described above were filtered through a $0.45 \mu \mathrm{m}$ polytetrafluoroethylene (PTFE) membrane into HPLC vials and subjected to HPLC analysis to draw standard curves. 
Mixed $100 \mathrm{mg}$ litre $^{-1}$ lutein $1 \mathrm{ml}, 100 \mathrm{mg}$ litre $^{-1}$ zeaxanthin $1 \mathrm{ml}$ and $600 \mathrm{mg}$ litre ${ }^{-1} \beta$-carotene $1 \mathrm{ml}$ in volumetric flask and dichloromethane was added in the volumetric flask to $10 \mathrm{ml}$. The solution was then filtered through a $0.45 \mu \mathrm{m}$ PTFE membrane into HPLC vials and subjected to HPLC analysis.

Egg yolk carotenoids concentration ( $\mu \mathrm{g} \mathrm{g}^{-1}$ yolk) was analysed by HPLC. Yolk samples were analysed within six months after egg collection (Hargitai et al., 2016), hence we did not expect a considerable reduction in carotenoids levels.

According to the Association of Official Analytical Chemists (AOAC) method, the spectroscopic determination of total carotenoids is equal to the spectroscopic determination of $\beta$-carotene (Islam and Schweigert, 2015). 1.08 $\mathrm{mg}$ of $\beta$-carotene standard was dissolved in dichloromethane (Concentrations 2.16, 3.24, 5.4, 10.8, 21.6, 32.4, 54 and $108 \mathrm{mg}_{\text {litre }}{ }^{-1}$ ) with optical density (OD) value at $450 \mathrm{~nm}$. A standard curve line of best fit was then constructed to derive the relationship between OD value and carotenoid concentration.

Total carotenoid extractions were carried out using the methodology described by ParedesMolina et al. (2016), with some slight modifications. The carotenoids composition of the test diets (Table 2) and the egg yolks were determined using HPLC analysis (Agilent Technologies Co. Ltd., China). Accordingly, $3 \mathrm{~g}$ of egg yolks (five per group)/ poultry feed was extracted in $15 \mathrm{ml}$ of petroleum ether/acetone $(2: 1 \mathrm{v} / \mathrm{v})$ in a Pyrex glass vial. Pyrex glass vials were sonicated using an ultrasonic bath (Kunshan Ultrasonic Instruments Co. Ltd., model KQ5200, China) for 5 min and then extracted for $60 \mathrm{~min}$ at room temperature $\left(25^{\circ} \mathrm{C}\right)$. The supernatants were transferred to new vials and the extraction procedure was repeated three more times. The volume of supernatant was set to $50 \mathrm{ml}$, its absorbance was determined at $450 \mathrm{~nm}$ using an ultraviolet spectrophotometer (INESA Analytical Instrument Co. Ltd., model $752 \mathrm{~N}$, China). The total carotenoid content was calculated based on the standard curve line derived above.

\begin{tabular}{lcccc}
\multicolumn{4}{c}{ TABLE 2. THE CONTENT OF CAROTENOIDS OF LAYING } \\
DUCK'S DIETS (g kg-1 \\
Item & $\begin{array}{c}\text { Control } \\
\text { group }\end{array}$ & $\begin{array}{c}\mathbf{1 \%} \text { \%PO } \\
\text { group }\end{array}$ & $\begin{array}{c}\mathbf{2 \%} \text { RPO } \\
\text { group }\end{array}$ & $\begin{array}{c}\mathbf{3} \% \mathbf{R P O} \\
\text { group }\end{array}$ \\
\hline Lutein & 6120 & 6690 & 6570 & 6600 \\
Zeaxanthin & 470 & 510 & 960 & 750 \\
$\beta$-carotene & 9810 & 13450 & 17750 & 24850 \\
Unknown & 14660 & 20680 & 25660 & 33590 \\
Total carotenoids & 18890 & 50640 & 60070 & 74990 \\
\hline
\end{tabular}

Note: RPO - red palm oil.
The sample extracts described above were filtered through a $0.45 \mu \mathrm{m}$ PTFE membrane into HPLC vials and subjected to HPLC analysis. The contents of individual carotenoids in egg yolks were quantified on the basis of the corresponding retention times and standard curves.

An Agilent Technologies HPLC system with a variable wavelength detector (VWD) at $450 \mathrm{~nm}$ was used for analysis of carotenoids. A precolumn with inner dimensions of $10 \mathrm{~mm} \times 4 \mathrm{~mm}$ was included before the column and held at room temperature. A column (YMC Europe GmbH, Dinslaken, Germany) with $5 \mu \mathrm{m} \mathrm{C} 30$ reverse phase material with inner dimensions of $250 \mathrm{~mm} \times 4.6 \mathrm{~mm}$ was used for separation. Mobile phases A methanol: acetonitrile = 25:75; mobile phases B: MTBE; mobile phases C: H2O. Gradient elution was performed with $0 \sim 15$ min: $\sim$ A $98 \% \sim 70 \%$, B 0 28\%, C 2\%; 15 20 min: A $70 \% \sim 18 \%$, B $28 \% \sim 80 \%$, C 2\%; 20 22 min: A 18\%, B $80 \%$, C $2 \%$; 22 23 min: A 18\% 0, B 80\% 100\%, C $2 \% \sim 0 ; 23 \sim 25 \mathrm{~min}:$ A $0 \sim 98 \%$, B 100\% 0, C 0 2\%. Column temperature was at room temperature and flow rate was $1 \mathrm{ml} \mathrm{min}^{-1}$. An $20 \mu \mathrm{l}$ sample extracts and standard solutions were injected.

\section{Extraction and Analysis of Yolk and Diet Fatty Acids}

The fatty acid composition of the test diets (Table 3) and the egg yolks were determined using standard gas chromatography (Agilent Technologies Co. Ltd., America) techniques of the fatty acid methyl esters (AOAC, 1990), using C17:1 fatty acid (Nu-Chek Prep Inc., Elysian, Minnesota) as an internal standard. Fatty acids were extracted from the egg yolk according to the methods of Folch et al. (1957). The diet subsamples were also stored at $-20^{\circ} \mathrm{C}$ before the fatty acids analysis (Couch et al., 1970).

\section{Determination of Total Cholesterol (TC) and Triglyceride (TG) in Egg Yolk and Serum}

Blood samples of all ducks were drawn from the wing vein, at the beginning and the end of the experimental period. The content of TC and TG in the egg yolk and serum was detected with a kit (Nanjing Jiancheng Bioengineering Institute, China), and the absorbance was measured using a microplate reader (Bio Tek, USA), and the content was calculated according to the formula.

\section{STATISTICAL ANALYSES}

All data were analysed using one-way ANOVA using SPSS 17 .0 statistics software (SPSS, Chicago, Illinois, USA). 
TABLE 3. FATTY ACID PROFILE OF LAYING DUCK'S DIETS

\begin{tabular}{lcccc}
\hline Fatty acids & $\begin{array}{c}\text { Control } \\
\text { group }\end{array}$ & $\begin{array}{c}\text { 1\% RPO } \\
\text { group }\end{array}$ & $\begin{array}{c}\text { 2\% RPO } \\
\text { group }\end{array}$ & $\begin{array}{c}\text { 3\% RPO } \\
\text { group }\end{array}$ \\
\hline C16:0 (\% $\left.{ }^{1}\right)$ & 11.80 & 18.07 & 18.02 & 24.08 \\
C18:0 (\%) & 3.21 & 3.27 & 3.36 & 3.45 \\
C18:1 (\%) & 24.68 & 26.71 & 27.07 & 29.48 \\
C18:2 n-6 (\%) & 52.95 & 49.69 & 44.81 & 36.95 \\
C20:1 (\%) & 5.29 & 0.79 & 4.10 & 2.96 \\
C22:0 (\%) & 0.47 & 0.03 & 0.32 & 0.32 \\
C20:5 n-3 (\%) & 0.17 & 0.08 & 0.17 & 0.17 \\
Others (\%) & 1.44 & 1.48 & 2.15 & 2.59 \\
SFA (\%) & 16.26 & 22.46 & 23.07 & 29.85 \\
MUFA (\%) & 30.11 & 27.65 & 31.45 & 32.64 \\
PUFA (\%) & 53.63 & 49.88 & 45.48 & 37.51 \\
n-3 PUFA (\%) & 0.19 & 0.20 & 0.20 & 0.20 \\
n-6 PUFA (\%) & 53.34 & 49.65 & 45.21 & 37.19 \\
Total (g/100 g & 5.9302 & 5.7350 & 5.6758 & 5.6197 \\
feed $)$ & & & & \\
\hline
\end{tabular}

Note: ${ }^{1}$ the percentage of individual fatty acids in total fatty acids; 2 the mass of fatty acids contained in $100 \mathrm{~g}$ of feed; RPO - red palm oil, SFA - saturated fatty acid, MUFA monounsaturated fatty acid, PUFA - polymonounsaturated fatty acid.

\section{RESULTS}

\section{Carotenoids and Fatty Acid Profile of the Diets}

The individual carotenoids levels in each diet are as shown in Table 2. The total carotenoids in the control group diet was lower than that in the RPO group diets. The carotenoids in the RPO were mainly $\beta$-carotene, with small amounts of lutein. Therefore, the concentration of carotenoids was increased with the increase of RPO content in the experimental diets. The total carotenoids content in the $30 \mathrm{~g} \mathrm{~kg}^{-1}$ RPO group was about 3.97 times than that of the control group.

The fatty acid profile in the control and experimental diet are as shown in Table 3. The total fatty acid content of the feeds in each group was similar (5.62 to $5.93 \mathrm{~g} / 100 \mathrm{~g}$ feed). Adding RPO to the feed can significantly increase the content of SFA and MUFA such as palmitic acid, stearic acid and oleic acid in the feed, while the content of PUFA such as linoleic acid is significantly reduced, and the content of n-3 PUFA in each group is similar. The content of n-6 PUFA decreases with the increase of RPO content.

\section{Effects of RPO on the Productive Performance}

As shown in Table 4, the average daily feed intake and laying rate of feed treatment groups of $10 \mathrm{~g} \mathrm{~kg}^{-1}$ and $20 \mathrm{~g} \mathrm{~kg}^{-1}$ were significantly higher than the control group $(P<0.05)$. Furthermore, the laying rate of group with $\mathrm{RPO}$ at $30 \mathrm{~g} \mathrm{~kg}^{-1}$ was significantly lower than the groups with RPO at $10 \mathrm{~g} \mathrm{~kg}^{-1}$ and 20 $\mathrm{g} \mathrm{kg}^{-1}(P<0.05)$. However, there was no significant difference observed for the feed conversion rate in the RPO groups compared with the control group $(P>0.05)$ (Table 4).

\section{Effects of RPO on Egg Quality of Ducks}

All levels of RPO meal used in this study had no effect on average egg weight, albumen height and Haugh unit $(P>0.05)$ (Table 5). However, there was a significant difference in egg yolk colour of RPO groups compared with the control group $(P<0.05)$. There was a dose-response relationship between egg yolk colour and RPO concentration in the feed. Yolk colour changed significantly $(P<0.001)$ with the RPO concentration $(P<0.05)$, and the eggs of RPO at $30 \mathrm{~g}$ $\mathrm{kg}^{-1}$ group had the highest colour concentration of egg yolk.

\section{Carotenoids Levels in Egg Yolk}

Lutein, $\beta$-carotene and total carotenoids in the egg yolk changed significantly $(P<0.05)$ after feeding RPO (Table 6). After eight weeks of RPO intervention, the content of lutein and total carotenoids in the group with RPO at $30 \mathrm{~g} \mathrm{~kg}^{-1}$ was significantly higher than those in the control group and groups with $\mathrm{RPO}$ at $10 \mathrm{~g} \mathrm{~kg}^{-1}$ and $20 \mathrm{~g} \mathrm{~kg}^{-1}(P<0.05)$. After eight weeks of intervention, the content of $\beta$-carotene in

\begin{tabular}{lccccccc}
\multicolumn{7}{c}{ TABLE 4. EFFECTS OF RPO SUPPLEMENTATION TO LAYING DUCKS ON WEIGHT AND } \\
PRODUCTIVE PERFORMANCE (mean \pm SD)
\end{tabular}

Note: ${ }^{a, b}$ In the same row, values with the different symbol superscripts mean significant differences $(\mathrm{P}<0.05)$, while with the same or no symbol superscripts mean no significant differences ( $\mathrm{P}>0.05)$; RPO - red palm oil; $\mathrm{F}$ - statistical value; $\mathrm{P}$ - intragroup comparison for changes in the parameters. 
TABLE 5. EFFECTS OF RPO ON EGG QUALITY OF LAYING DUCKS AFTER FEEDING EIGHT WEEKS (mean \pm SD) (n=10)

\begin{tabular}{|c|c|c|c|c|c|c|c|}
\hline & Item & $\begin{array}{l}\text { Control } \\
\text { group }\end{array}$ & $\begin{array}{l}1 \% \mathrm{RPO} \\
\text { group }\end{array}$ & $\begin{array}{l}2 \% \mathrm{RPO} \\
\text { group }\end{array}$ & $\begin{array}{l}3 \% \mathrm{RPO} \\
\text { group }\end{array}$ & $\mathbf{F}$ & $\mathbf{P}$ \\
\hline \multirow{4}{*}{ Baseline } & Average egg weight /g & $77.28 \pm 4.82$ & $80.14 \pm 6.22$ & $78.97 \pm 6.76$ & $79.08 \pm 5.82$ & 0.395 & 0.757 \\
\hline & Albumen height / mm & $7.46 \pm 1.12$ & $7.26 \pm 0.84$ & $7.06 \pm 1.57$ & $6.76 \pm 1.72$ & 0.484 & 0.695 \\
\hline & Yolk colour score & $9.09 \pm 1.21$ & $9.08 \pm 0.69$ & $8.95 \pm 0.84$ & $9.34 \pm 0.55$ & 0.359 & 0.783 \\
\hline & Haugh unit & $81.22 \pm 7.55$ & $79.26 \pm 6.13$ & $77.25 \pm 11.40$ & $79.31 \pm 6.47$ & 0.391 & 0.761 \\
\hline \multirow{4}{*}{ Eight weeks } & Average egg weight /g & $71.20 \pm 8.75$ & $72.57 \pm 5.29$ & $72.44 \pm 4.21$ & $74.90 \pm 5.55$ & 0.623 & 0.605 \\
\hline & Albumen height / mm & $7.49 \pm 0.61$ & $8.15 \pm 1.29$ & $7.11 \pm 0.88$ & $8.38 \pm 1.56$ & 2.627 & 0.065 \\
\hline & Yolk colour score & $9.02 \pm 0.68^{\mathrm{a}}$ & $9.83 \pm 0.48^{\mathrm{b}}$ & $10.22 \pm 0.77^{b, c}$ & $10.60 \pm 0.24^{\mathrm{c}}$ & 12.803 & \\
\hline & Haugh unit & $83.54 \pm 3.92$ & $86.52 \pm 6.65$ & $80.38 \pm 6.73$ & $85.06 \pm 7.86$ & 1.669 & 0.191 \\
\hline
\end{tabular}

Note: ${ }^{a, b}$ In the same row, values with the different symbol superscripts mean significant differences $(\mathrm{P}<0.05)$, while with the same or no symbol superscripts mean no significant differences $(\mathrm{P}>0.05)$; RPO - red palm oil; F - statistical value; P - intragroup comparison for changes in the parameters.

TABLE 6. EFFECTS OF RPO SUPPLEMENTATION TO LAYING DUCKS ON CAROTENOIDS LEVELS IN EGG YOLK

\begin{tabular}{|c|c|c|c|c|c|c|c|}
\hline & Carotenoids & $\begin{array}{l}\text { Control } \\
\text { group }\end{array}$ & $\begin{array}{l}1 \% \mathrm{RPO} \\
\text { group }\end{array}$ & $\begin{array}{l}2 \% \mathrm{RPO} \\
\text { group }\end{array}$ & $\begin{array}{c}3 \% \mathrm{RPO} \\
\text { group }\end{array}$ & $\mathbf{F}$ & $\mathbf{P}$ \\
\hline \multirow{4}{*}{ Baseline } & Lutein ( $\mu \mathrm{g} \mathrm{g}^{-1}$ yolk) & $12.69 \pm 0.28$ & $12.35 \pm 0.74$ & $12.47 \pm 0.54$ & $12.33 \pm 0.90$ & 0.267 & 0.848 \\
\hline & Zeaxanthin ( $\mu \mathrm{g} \mathrm{g}^{-1}$ yolk$)$ & $9.01 \pm 1.09$ & $9.17 \pm 2.00$ & $840+10$ & $9.03 \pm 1.25$ & 0.225 & 0.878 \\
\hline & $\beta$-carotene ( $\mu \mathrm{g} \mathrm{g}^{-1}$ yolk) & $8.02 \pm 0.09$ & $7.97 \pm 0.07$ & $8.00 \pm 0.11$ & $8.03 \pm 0.08$ & 0.481 & 0.700 \\
\hline & Total carotenoids ( $\mu \mathrm{g} \mathrm{g}^{-1}$ yolk) & $34.70 \pm 1.85$ & $34.90 \pm 4.01$ & $37.32 \pm 2.24$ & $37.60 \pm 0.92$ & 1.884 & 0.173 \\
\hline \multirow{4}{*}{$\begin{array}{l}\text { After eight } \\
\text { weeks }\end{array}$} & Lutein $\left(\mu \mathrm{g} \mathrm{g}^{-1}\right.$ yolk$)$ & $12.98 \pm 0.47^{\mathrm{a}}$ & $12.25 \pm 0.92^{\mathrm{a}}$ & $13.16 \pm 0.95^{\mathrm{a}}$ & $28.09 \pm 6.71^{b}$ & 23.515 & $<0.001$ \\
\hline & Zeaxanthin ( $\mu \mathrm{g} \mathrm{g}^{-1}$ yolk) & $9.79 \pm 1.26$ & $9.62 \pm 1.92$ & $10.43 \pm 1.22$ & $10.09 \pm 2.11$ & 0.224 & 0.878 \\
\hline & $\beta$-carotene $\left(\mu \mathrm{g} \mathrm{g}^{-1}\right.$ yolk$)$ & $7.94 \pm 0.07^{\mathrm{a}}$ & $8.13 \pm 0.17^{a}$ & $8.86 \pm 0.24^{\mathrm{b}}$ & $9.97 \pm 0.93^{c}$ & 18.609 & $<0.001$ \\
\hline & Total carotenoids ( $\mu \mathrm{g} \mathrm{g}^{-1}$ yolk) & $36.61 \pm 2.90^{\mathrm{a}}$ & $40.46 \pm 9.44^{\mathrm{a}}$ & $41.53 \pm 1.75^{\mathrm{a}}$ & $58.22 \pm 9.02^{b}$ & 9.051 & 0.001 \\
\hline
\end{tabular}

Note: ${ }^{a, b, c}$ In the same row, values with the different symbol superscripts mean significant differences (P<0.05), while with the same or no symbol superscripts mean no significant differences ( $\mathrm{P}>0.05)$; RPO - red palm oil; F - statistical value; P - intragroup comparison for changes in the parameters.

the yolk had gradually increased with the increase of RPO content in the diet $(P<0.05)$. The content of $\beta$-carotene in the groups with RPO at $20 \mathrm{~g} \mathrm{~kg}^{-1}$ and $30 \mathrm{~g} \mathrm{~kg}^{-1}$ was significantly higher than that in the control group. In the RPO group $(P<0.05)$, the content of $\beta$-carotene in yolk was highest in the group with RPO at $30 \mathrm{~g} \mathrm{~kg}^{-1}$.

\section{TC and TG Content of Serum and Eggs}

RPO had a significant effect on serum TG, yolk TC and yolk TG contents in duck eggs $(P<0.05)$. The serum TG, yolk TC and yolk TG contents in RPO groups were significantly lower than those in the control group, but there was no significant difference among the three RPO groups. The effect of RPO on serum TC in laying ducks was not significant $(P>0.05)$ (Table 7).

\section{Fatty Acids Levels in Egg Yolk}

Main fatty acids of egg yolk in the control group are linoleic acid and palmitic acid, while the main fatty acids in egg yolk of the RPO groups, are oleic acid and palmitic acid. After eight weeks of RPO feeding, the contents of SFA and MUFA in the RPO groups were higher than those in the control group $(P<0.001)$, and the content of MUFA in the egg yolk had also gradually increased with the increase of RPO content in the feed. The content of PUFA in the egg yolk of each group had decreased with the increase of RPO content in the feed $(P<0.001)$. The total fatty acid content of yolk in each RPO group was slightly lower than that in the control group but the difference was not statistically significant $(P>0.05)$ (Table 8).

\section{DISCUSSION}

\section{Effects of RPO on the Productive Performance and Egg Quality of Ducks}

This study found that the feed intake of RPO groups were higher than that of the control group $(\mathrm{P}<0.05)$. The egg laying rate of each $\mathrm{RPO}$ groups had no significant difference compared with the 
RED PALM OIL IN LAYING DUCKS DIETS: EFFECTS ON PRODUCTIVE PERFORMANCE, EGG QUALITY, CONCENTRATIONS OF YOLK CAROTENOIDS

TABLE 7. EFFECTS OF RED PALM OIL SUPPLEMENTATION TO LAYING DUCKS ON SERUM AND EGG YOLK LIPID INDICES (mean \pm SD) $(n=12)$

\begin{tabular}{|c|c|c|c|c|c|c|c|}
\hline & Item & $\begin{array}{l}\text { Control } \\
\text { group }\end{array}$ & $\begin{array}{l}1 \% \mathrm{RPO} \\
\text { group }\end{array}$ & $\begin{array}{l}2 \% \mathrm{RPO} \\
\text { group }\end{array}$ & $\begin{array}{l}3 \% \mathrm{RPO} \\
\text { group }\end{array}$ & $\mathbf{F}$ & $\mathbf{P}$ \\
\hline \multirow{4}{*}{ Baseline } & Serum TC/ (mmol litre $\left.{ }^{-1}\right)$ & $4.63 \pm 1.78$ & $4.43 \pm 1.90$ & $3.96 \pm 1.17$ & $4.10 \pm 1.07$ & 0.456 & 0.714 \\
\hline & Serum TG/(mmol litre $\left.{ }^{-1}\right)$ & $19.81 \pm 5.56$ & $18.78 \pm 4.24$ & $17.13 \pm 3.35$ & $18.78 \pm 4.48$ & 0.688 & 0.564 \\
\hline & Yolk TC/ (mmol g ${ }^{-1}$ yolk) & $6.75 \pm 3.31$ & $6.78 \pm 3.12$ & $7.84 \pm 2.50$ & $7.69 \pm 3.21$ & 0.359 & 0.783 \\
\hline & Yolk TG/ (mmol g ${ }^{-1}$ yolk) & $41.65 \pm 10.14$ & $41.71 \pm 8.70$ & $44.74 \pm 8.95$ & $42.29 \pm 7.99$ & 0.264 & 0.851 \\
\hline \multirow{4}{*}{$\begin{array}{l}\text { After eight } \\
\text { weeks }\end{array}$} & Serum TC/ (mmol litre $\left.{ }^{-1}\right)$ & $4.61 \pm 1.85$ & $6.02 \pm 1.78$ & $5.46 \pm 2.00$ & $3.86 \pm 2.03$ & 2.800 & 0.052 \\
\hline & Serum TG/ (mmol litre ${ }^{-1}$ ) & $17.07 \pm 5.82^{\mathrm{a}}$ & $9.86 \pm 8.31^{\mathrm{b}}$ & $7.14 \pm 5.87^{\mathrm{b}}$ & $6.45 \pm 4.48^{\mathrm{b}}$ & 6.378 & \\
\hline & Yolk TC/ (mmol g ${ }^{-1}$ yolk) & $7.78 \pm 2.54^{\mathrm{a}}$ & $4.74 \pm 2.67^{\mathrm{b}}$ & $4.76 \pm 1.62^{\mathrm{b}}$ & $5.36 \pm 0.85^{\mathrm{b}}$ & 4.952 & \\
\hline & Yolk TG/ (mmol g ${ }^{-1}$ yolk) & $44.10 \pm 9.69^{\mathrm{a}}$ & $32.76 \pm 7.17^{\mathrm{b}}$ & $28.78 \pm 7.95^{\mathrm{b}}$ & $31.50 \pm 6.73^{\mathrm{b}}$ & 7.016 & 0.001 \\
\hline
\end{tabular}

Note: ${ }^{a, b}$ In the same row, values with the different symbol superscripts mean significant differences(P<0.05), while with the same or no symbol superscripts mean no significant differences ( $>>0.05)$; RPO - red palm oil; TC - total cholesterol; TG - triglyceride; F - statistical value; $\mathrm{P}$ - intragroup comparison for changes in the parameters.

TABLE 8. EFFECT OF DIETARY OIL ON THE FATTY ACID IN EGG YOLK AFTER FEEDING RPO (percentage of total fatty acids)

\begin{tabular}{|c|c|c|c|c|c|c|}
\hline Fatty acids & Control group & $1 \%$ RPO group & $2 \%$ RPO group & $3 \%$ RPO group & F & $\mathbf{P}$ \\
\hline C16:0 & $21.55 \pm 0.35^{\mathrm{a}}$ & $23.94 \pm 0.94^{\mathrm{b}, \mathrm{c}}$ & $23.14 \pm 0.23^{b}$ & $24.61 \pm 0.24^{\mathrm{c}}$ & 27.830 & $<0.001$ \\
\hline C16:1 & $1.94 \pm 0.21^{\mathrm{a}}$ & $2.19 \pm 0.43^{a, b}$ & $2.27 \pm 0.06^{\mathrm{a}, \mathrm{b}}$ & $2.51 \pm 0.20^{\mathrm{b}}$ & 3.519 & 0.043 \\
\hline C18:0 & $0.66 \pm 0.14^{\mathrm{a}}$ & $1.47 \pm 0.10^{\mathrm{b}}$ & $1.25 \pm 0.71^{\mathrm{b}}$ & $1.32 \pm 0.15^{\mathrm{b}}$ & 7.070 & 0.004 \\
\hline C18:1 & $5.97 \pm 0.48^{\mathrm{a}}$ & $51.25 \pm 1.59^{\mathrm{b}}$ & $53.09 \pm 2.17^{\mathrm{b}, \mathrm{c}}$ & $54.01 \pm 0.95^{c}$ & 1533.562 & $<0.001$ \\
\hline C18:2 n-6 & $60.64 \pm 0.58^{a}$ & $11.58 \pm 0.38^{\mathrm{b}}$ & 10 & $9.38 \pm 0.79^{c}$ & 1939.649 & $<0.001$ \\
\hline C18:3 n-6 & $0.22 \pm 0.04^{\mathrm{a}}$ & $0.23 \pm 0.02^{\mathrm{a}}$ & $0.18 \pm 0.01^{b}$ & $0.17 \pm 0.01^{b}$ & 6.449 & 0.006 \\
\hline C18:3 n-3 & $1.05 \pm 0.05$ & $0.53 \pm 0.35$ & $0.66 \pm 0.56$ & $0.42 \pm 0.34$ & 3.275 & 0.053 \\
\hline C20:2 & $0.34 \pm 0.04^{\mathrm{a}}$ & $0.24 \pm 0.02^{b}$ & $21 \pm 0.05^{\mathrm{b}}$ & $0.22 \pm 0.02^{\mathrm{b}}$ & 16.573 & $<0.001$ \\
\hline C20:3 n-6 & $0.43 \pm 0.05^{\mathrm{a}}$ & $.35 \pm 0.04^{\mathrm{a}, \mathrm{b}}$ & $0.29 \pm 0.11^{b}$ & $0.38 \pm 0.02^{a, b}$ & 4.693 & 0.018 \\
\hline C20:4 n-6 & $4.71 \pm 0.14$ & $5.13 \pm 0.41$ & $3.97 \pm 1.28$ & $4.35 \pm 0.46$ & 2.819 & 0.077 \\
\hline $\mathrm{C} 24: 1$ & $0.51 \pm 0.11$ & $0.59 \pm 0.08$ & $0.46 \pm 0.04$ & $0.45 \pm 0.03$ & 3.164 & 0.058 \\
\hline$C 22: 6 n-3$ & $1.00 \pm 0.16^{\mathrm{a}}$ & $0.94 \pm 0.15^{\mathrm{a}}$ & $1.00 \pm 0.32^{\mathrm{a}}$ & $0.61 \pm 0.07^{\mathrm{b}}$ & 5.611 & 0.010 \\
\hline SFA & $23.05 \pm 0.23^{\mathrm{a}}$ & $26.30 \pm 1.06^{c}$ & $25.16 \pm 0.71^{b}$ & $26.88 \pm 0.36^{c}$ & 32.201 & $<0.001$ \\
\hline MUFA & $8.58 \pm 0.35^{\mathrm{a}}$ & $54.63 \pm 1.02^{\mathrm{b}}$ & $56.90 \pm 2.38^{c}$ & $57.51 \pm 0.68^{c}$ & 2162.841 & $<0.001$ \\
\hline PUFA & $68.38 \pm 0.54^{\mathrm{a}}$ & $19.07 \pm 0.59^{b}$ & $17.94 \pm 1.87^{b}$ & $15.61 \pm 0.66^{c}$ & 3895.144 & $<0.001$ \\
\hline n-3 PUFA & $2.26 \pm 0.12^{a}$ & $1.76 \pm 0.46^{\mathrm{b}}$ & $1.85 \pm 0.75^{\mathrm{b}}$ & $1.24 \pm 0.33^{\mathrm{b}}$ & 4.943 & 0.015 \\
\hline n-6 PUFA & $66.00 \pm 0.63^{\mathrm{a}}$ & $17.30 \pm 0.19^{b}$ & $16.63 \pm 1.64^{\mathrm{b}}$ & $14.31 \pm 0.62^{c}$ & 4889.944 & $<0.001$ \\
\hline Others & $0.69 \pm 0.04^{\mathrm{a}}$ & $1.21 \pm 0.64 \mathrm{a}, \mathrm{b}$ & $1.68 \pm 0.04^{\mathrm{b}}$ & $1.16 \pm 0.49^{a, b}$ & 3.427 & 0.047 \\
\hline Total & $45.70 \pm 1.01$ & $34.84 \pm 8.09$ & $35.95 \pm 6.26$ & $44.34 \pm 3.24$ & 4.538 & 0.059 \\
\hline
\end{tabular}

Note: ${ }^{a, b, c}$ In the same row, values with the different symbol superscripts mean significant differences (P<0.05), while with the same or no symbol superscripts mean no significant differences ( $>>0.05)$; RPO - red palm oil; SFA - saturated fatty acid, MUFA monounsaturated fatty acid; PUFA - polymonounsaturated fatty acid; F - statistical value; P - intragroup comparison for changes in the parameters.

control group $(\mathrm{P}>0.05)$ but the egg laying rate of the group with RPO at $30 \mathrm{~g} \mathrm{~kg}^{-1}$ was significantly lower than that in the groups with RPO at $10 \mathrm{~g} \mathrm{~kg}^{-1}$ and 20 $\mathrm{g} \mathrm{kg}^{-1}(\mathrm{P}<0.05)$. It is suggested that short-term RPO and soyabean oil intake had no effect on egg laying rate of the ducks $(\mathrm{P}>0.05)$ but rather the intervention of high-dose $\left(30 \mathrm{~g} \mathrm{~kg}^{-1}\right) \mathrm{RPO}$ may reduce egg laying rate $(\mathrm{P}<0.05)$. This suggests that there is a limit to using RPO, which should be paid attention in practicality to derive the maximum quality of the 
product and reap economic benefits. This is likely because RPO in itself has a special odour and colour which did not change drastically when a low dose is added to the feed. However, the content of nutrients such as carotenoids and vitamin E in the feed could be increased, thereby increasing the yield. When the ratio of addition is increased, the feed odour and colour can also change drastically, thereby affecting the feed intake, digestion and utilisation of laying ducks. However, studies have shown that feeding Cambrian duck with soyabean oil $(2 \%)$ or PO $(2 \%)$ did not affect the growth and development of ducks (weight) $(P>0.1)$, nor does it affect the feed intake of the ducks $(P>0.1)$ (Zosangpuii et al., 2015).

All levels of RPO meal used in this study had no effect on the average egg weight, albumen height and Haugh unit $(P>0.05)$. It is suggested that shortterm RPO intake had no effect on egg quality of laying ducks compared with soyabean oil $(\mathrm{P}>0.05)$.

\section{Effects of RPO on the Egg Yolk Colour and Carotenoids Levels}

After eight weeks of RPO intervention, there was a significant difference in egg yolk colour of RPO groups compared with the control group $(\mathrm{P}<0.05)$. There was a dose-response relationship between egg yolk colour and RPO concentration in the feed. Yolk colour had changed significantly $(\mathrm{P}<0.001)$ with the RPO concentration $(P<0.05)$, and the eggs of the group with RPO at $30 \mathrm{~g} \mathrm{~kg}^{-1}$ had the highest colour of egg yolk. The results of this study suggest that adding RPO to feed can significantly improve the colour of egg yolk, and the level of yolk colour showed a significant upward trend with the increase of RPO in the diet. Further research found that RPO can increase the content of lutein, $\beta$-carotene and total carotenoids in egg yolk, with varying degrees $(\mathrm{P}<0.05)$, and the level of lutein, $\beta$-carotene and total carotenoids had increased with the increase of RPO in the diet. Since there was no zeaxanthin in RPO, there was no significant difference in yolk zeaxanthin content between the groups. This is consistent with the composition and content of carotenoids in RPO.

The traditional raw materials used in poultry feed usually do not provide sufficient carotenoids to achieve the yolk pigmentation demanded by consumers, so colour additives are included commonly in the form of carotenoid-rich dried plant extracts. Many studies focus on how to improve the colour of eggs to reap higher benefits. For example, Moreno et al. (Moreno et al., 2020) used carotenoidenriched maize, while Titcomb et al. (Titcomb et al., 2019) used carrot leaves and marigold fortification. RPO is rich in carotenoids, and the carotenoids content in the diet of each RPO group is also significantly higher than that of the control group. From this study, the carotenoids in RPO can be effectively absorbed and converted into egg yolk by ducks and effectively improve the colour of egg yolk.

\section{Effect of RPO on Serum Lipid Level and Egg Yolk Lipid Content}

Research has shown that the lipid composition and fatty acid profile of an egg can be influenced by dietary manipulation (Ouyang et al., 2004). After eight weeks of RPO intervention, serum TG, yolk TC and yolk TG level in each RPO groups were significantly lower than those in controlgroup, which may be related to the sn-2 hypothesis, and may also be related to the rich tocotrienols and carotenoids in RPO. Studies have shown that tocotrienols can reduce the activity of HMG Co-A reductase (a ratelimiting enzyme in the synthesis of cholesterol in liver cells) and act as oxysterols to lower cholesterol level (Pearce et al., 1992). Tocotrienol in PO is more efficient to transfer to the egg yolk than other oils (barley oil) (Walde et al., 2014).

Further research found that because RPO contains approximately $44.13 \%$ SFA (mainly palmitic acid, $36.82 \%$ ) and $43.36 \%$ MUFA (mainly oleic acid, $43.08 \%$ ), the content of SFA (palmitic acid) and MUFA (oleic acid) in the egg yolk increased significantly with the increase of RPO in diets. Due to RPO has a low contain of PUFA, approximately $12.49 \%$, dietary RPO had decreased the content of PUFA in egg yolk $(\mathrm{P}<0.05)$.

\section{CONCLUSION}

Eggs are regarded as one of the nature's most wholesome foods because they contain highquality protein and lipids as well as essential and non-essential minerals and vitamins. Studies have shown that the bioavailability of lutein in eggs is high, which may be related to the fat contained in the egg yolk. Adding appropriate amount of RPO (10 $\mathrm{g} \mathrm{kg}^{-1}$ and $20 \mathrm{~g} \mathrm{~kg}^{-1}$ in this article) may have the potential to increase the laying rate, bring the possibility of increasing production and increase people's income. The results of this study showed that dietary RPO can significantly increase egg yolk colour, increase carotenoids content in egg yolk and reduce certain lipid indicators, which could be more attractive to customers. In summary, RPO as a green and safe feed colourant deserves further development and promotion.

\section{ACKNOWLEDGEMENT}

We thank the support from Postgraduate Research and Practice Innovation Program of Jiangsu Province (KYCX20_0154) and thank all those who have contributed to this article. 


\section{REFERENCES}

Abiodun, B S; Adedeji, A S and Abiodun, E (2014). Lesser known indigenous vegetables as potential natural egg colourant in laying chickens. J. Anim. Sci. Technol., 56: 18.

Akter, Y; Kasim, A; Omar, H and Sazili, A Q (2014). Effect of dietary crude palm oil on quality and oxidative stability of chicken eggs. J. Food, Agriculture and Environment, 12: 292-294.

Andreu-Sevill, A J; Hartmann, A; Burlo, F; Poquet, N and Carbonell-Barrachina, A A (2009). Health benefits of using red palm oil in deep-frying potatoes: Low acrolein emissions and high intake of carotenoids. Food Science and Technology International, 15: 15-22.

Buchanan, N P and Moritz, J S (2009). Main effects and interactions of varying formulation protein, fiber and moisture on feed manufacture and pellet quality. The J. Applied Poultry Research, 18: 274-283.

Chaturvedi, P A and Chaturvedi, A (2000). Effect of feeding crude red palm oil (Elaeis guineensis) and grain amaranth (Amaranthus paniculatus) to hens on total lipids, cholesterol, PUFA levels and acceptability of eggs. Plant Foods for Human Nutrition, 55: 147-157.

Cherian, G; Wolfe, F W and Sim, J S (1996). Dietary oils with added tocopherols: Effects on egg or tissue tocopherols, fatty acids, and oxidative stability. Poultry Science, 75: 423-431.

Couch, J R; Cornett, B M; Ferguson, T M and Creger, C R (1970). Effect of dietary fat on the fatty acid composition of turkey egg yolks.

FEEDAP (2014). Scientific opinion on the safety and efficacy of canthaxanthin as a feed additive for poultry and for ornamental birds and ornamental fish. EFSA Journal, 12, 3527-n/a. Panel on Additives and Products or Substances Used in Animal Feed (FEEDAP).

Fletcher, D L (1999). Broiler breast meat colour variation, $\mathrm{pH}$ and texture. Poultry Science, 78: 1323-7.

Fraeye, I; Bruneel, C; Lemahieu, C; Buyse, J; Muylaert, $\mathrm{K}$ and Foubert, I (2012). Dietary enrichment of eggs with omega-3 fatty acids: A review. Food Research International, 48: 961-969.

Go, R E; Hwang, K A; Kim, Y S; Kim, S H; Nam, K H and Choi, K C (2015). Effects of palm and sunflower oils on serum cholesterol and fatty liver in rats. J. Medicinal Food, 18: 363-369.
Gouk, S W; Cheng, S F; Mok, J S; Ong, A S and Chuah, C H (2013). Long-chain SFA at the sn-1, 3 positions of TAG reduce body fat deposition in C57BL / 6 mice. British J. Nutrition, 110: 1987-95.

Hammershoj, M; Kidmose, U and Steenfeld, S (2010). Deposition of carotenoids in egg yolk by short-term supplement of coloured carrot (Daucus carota) varieties as forage material for egg-laying hens. J. Science Food and Agriculture, 90: 1163-1171.

Hargitai, R; Boross, N; Nyiri, Z and Eke, Z (2016). Biliverdin-and protoporphyrin-based eggshell pigmentation in relation to antioxidant supplementation, female characteristics and egg traits in the canary (Serinus canaria). Behavioural Ecology and Sociobiology, 70: 2093-2110.

Hornstra, G (1987). Effect of dietary palm oil on arterial thrombus formation and prostanoid production in rats. Agents and Actions, 22: 377-378.

Islam, K M and Schweiger, F J (2015). Comparison of three spectrophotometric methods for analysis of egg yolk carotenoids. Food Chemistry, 172: 233-237.

Karadas, F; Grammenidis, E; Surai, P F; Acamovic, $\mathrm{T}$ and Sparks, N H (2006). Effects of carotenoids from lucerne, marigold and tomato on egg yolk pigmentation and carotenoid composition. British Poultry Science, 47: 561-566.

Keat, O C; May, C Y and Hock, A O (1991). Recovery of carotenoids. Google Patents.

Kijparkorn, S; Plaimast, $\mathrm{H}$ and Wangsoonoen, S (2010). Sano (Sesbania javanica Miq.) flower as a pigment source in egg yolk of laying hens. Thai J. Veterinary Medicine, 40: 281-287.

Ma, S (2015). Meta-analysis of the relationship between palm oil and human blood lipid and dietary intervention experiment. MSc. thesis, Yangzhou University.

Mizurini, D D; Maia, I D; Sardinha, F L D; Monteiro, R D; Ortiz-Costa, S and Do Carmo, M D T (2011). Venous thrombosis risk: Effects of palm oil and hydrogenated fat diet in rats. Nutrition, 27: 233 -238 .

Moreno, J A; Diaz-gomez, J; Fuentes-Font, L; Angulo, E; Gosalvez, L F; Sandmann, G; Porterootin, M; Capell, T; Zhu, C; Christou, P and Nogareda, C (2020). Poultry diets containing (keto) carotenoid-enriched maize improve egg yolk colour and maintain quality. Animal Feed Science and Technology, 260. https://doi.org/10.1016/j. anifeedsci.2019.114334 
Nagendran, B; Unnithan, U; Choo, Y and Sundram, K (2000). Characteristics of red palm oil, a caroteneand vitamin E-rich refined oil for food uses. Food and Nutrition Bulletin, 21: 189-194.

Nawab, A; Li, G; Liu, W; Lan, R; Wu, J; Zhao, Y; Kang, K; Kieser, B; Sun, C; Tang, S; Xiao, M and An, L (2019). Effect of dietary curcumin on the antioxidant status of laying hens under high-temperature condition. J. Therm. Biol., 86: 102449.

Nyquist, N F R; Dbotten, R; Thomassen, M and Haug, A (2013). Chicken meat nutritional value when feeding red palm oil, palm oil or rendered animal fat in combinations with linseed oil, rapeseed oil and two levels of selenium. Lipids in Health and Disease, 12(69). https: / / doi.org/10.1186/1476-511X-12-69.

Ooi, C; Choo, Y and Ong, A (1993). Refining of edible oil. Malaysian Patent MY-104059A.

Ouyang, K; Wang, W J; Xu, M S; Jiang, Y and Shangguan, X C (2004). Effects of different oils on the production performances and polyunsaturated fatty acids and cholesterol level of yolk in hens. Asian-Australasian J. Animal Sciences, 17: 843-847.

Paredes-Molina, F J; Cubillos, V M; Montory, J A and Andrade-Villagr, N P A (2016). Are embryonic developing modes determinant in the acquisition and levels of photoprotective compounds in slipper limpets of the Crepipatella genus? J. Photochemistry and Photobiology B: Biology, 162: 511-518.

Pearce, B C; Parker, R A; Deason, M E; Qureshi, A A and Wright, J J K (1992). Hypocholesterolemic activity of synthetic and natural tocotrienols. J. Medicinal Chemistry, 35: 3595-3606.

Rauchova, H; Vokurkov, M; Pavelka, S; Vaneckova, I; Tribulova, N and Soukup, T (2018). Red palm oil supplementation does not increase blood glucose or serum lipids levels in Wistar rats with different thyroid status. Physiol. Res., 67: 307-315.
Rice, A L and Burns, J B (2010). Moving from efficacy to effectiveness: Red palm oil's role in preventing vitamin A Deficiency. J. American College of Nutrition, 29: 302-313.

Spasevski, N; Peulic, T; Banjac, V; Colovic, R; Pezo, L; Rakita, S; Puvaca, N; Kokic, B; Duragic, O and Basic, Z (2020). Influence of extruded camelina seed and natural colourants addition laying hens diet on eggs yolk colour and fatty acid composition. J. Animal and Plant Sciences-Japs, 30: 1347-1356.

Sundram, K; Sambanthamurthi, R and Tan, Y A (2003). Palm fruit chemistry and nutrition. Asia Pacific J. Clinical Nutrition, 12: 355.

Titcomb, T J; Kaeppler, M S; Cook, M E; Simon, P W and Tanumihardjo, S A (2019). Carrot leaves improve color and xanthophyll content of egg yolk in laying hens but are not as effective as commercially available marigold fortificant. Poultry Science, 98: 5208-5213.

Walde, C M; Drotleff, A M and Ternes, W (2014). Comparison of dietary tocotrienols from barley and palm oils in hen's egg yolk: Transfer efficiency, influence of emulsification and effect on egg cholesterol. J. Science of Food and Agriculture, 94: 810-818.

Wilson, T A; Nicolosi, R J; Kotyla, T; Sundram, K and Kritchevsky, D (2005). Different palm oil preparations reduce plasma cholesterol concentrations and aortic cholesterol accumulation compared to coconut oil in hypercholesterolemic hamsters. The J. Nutritional Biochemistry, 16: 633640.

Zosangpuii; Patra, A K and Samanta, G (2015). Inclusion of an emulsifier to the diets containing different sources of fats on performances of Khaki Campbell ducks. Iranian J. Veterinary Research, 16: 156-160. 